\title{
Quicklime application instantly increases soil aggregate stability**
}

\author{
Katharina M. Keiblinger ${ }^{1}$, Lisa M. Bauer ${ }^{2}$, Evi Deltedesco ${ }^{1}$, Franz Holawe ${ }^{2}$, Hans Unterfrauner ${ }^{3}$, \\ Franz Zehetner ${ }^{1}$, and Robert Peticzka ${ }^{2}$ \\ ${ }^{1}$ Institute of Soil Research, Department of Forest and Soil Sciences, University of Natural Resources and Life Sciences Vienna \\ (BOKU), Peter Jordan-Strasse 82, 1190 Vienna, Austria \\ ${ }^{2}$ Department of Geography and Regional Research, University of Vienna, Universitätsstrasse 7, 1010 Vienna, Austria \\ ${ }^{3} \mathrm{~TB}$ Unterfrauner GmbH, Rochuspark Erdbergstraße 10/33, 1030 Vienna, Austria
}

Received August 20, 2015; accepted January 19, 2016

\begin{abstract}
A b s t r a c t. Agricultural intensification, especially enhanced mechanisation of soil management, can lead to the deterioration of soil structure and to compaction. A possible amelioration strategy is the application of (structural) lime. In this study, we tested the effect of two different liming materials, ie limestone $\left(\mathrm{CaCO}_{3}\right)$ and quicklime $(\mathrm{CaO})$, on soil aggregate stability in a 3-month greenhouse pot experiment with three agricultural soils. The liming materials were applied in the form of pulverised additives at a rate of $2000 \mathrm{~kg} \mathrm{ha}^{-1}$. Our results show a significant and instantaneous increase of stable aggregates after quicklime application whereas no effects were observed for limestone. Quicklime application seems to improve aggregate stability more efficiently in soils with high clay content and cation exchange capacity. In conclusion, quicklime application may be a feasible strategy for rapid improvement of aggregate stability of fine textured agricultural soils. $\mathrm{CaO}$

$\mathrm{K}$ e y w o r d s: stable aggregates, liming, quicklime, $\mathrm{CaCO}_{3}$,
\end{abstract}

\section{INTRODUCTION}

Agricultural production has strongly increased in the last decades due to enormous intensification of land management. This was accomplished through the application of fertilisers and pesticides, as well as irrigation and mechanisation (Matson et al., 1997). Intensive agriculture influences the chemistry, physics and biology of soils. Particularly, enhanced mechanisation in the form of farm machinery can cause soil compaction and deterioration of soil structure (Frey et al., 2009). Changing soil pore characteristics, such as total length and volume, affect soil water and air permeability, which in turn affects the soil as a biogeochemical interface for microbial life and a medium for plant growth. It is for this reason that the stability of the soil structure is a key for sustainable agriculture (Amezketa,

*Corresponding author e-mail: robert.peticzka@univie.ac.at

**This study was financially supported by BoWaSan/Bodenkalk e. Gen., Graz, Austria, Project No. 9836, 2013-2015.
1999) and an important mechanism for the stabilization of soil organic matter (Briedis et al., 2012; Oades, 1988). A promising approach to stabilise soil aggregates and thereby improve the water and air permeability of soils is the use of polyvalent ions like $\mathrm{Ca}^{2+}$ (Becher, 2001) applied to the topsoil in the form of pulverised limestone $\left(\mathrm{CaCO}_{3}\right)$ or quicklime $(\mathrm{CaO})$. The application of limestone is a common agricultural management practice (VDLUFA, 2000), as considerable increases in crop yields have been reported (Haynes and Naidu, 1998). However, the application of quicklime has so far not become a standard procedure in agricultural soil management, although it has recently been mentioned as 'structural lime' together with slaked lime applied to diminish P leaching (Bergström et al., 2015; Ulén and Etana, 2014). So far, lime-treatment stabilisation studies using quicklime have focused on engineering geology and civil engineering to improve fine textured soil in terms of engineering properties for earthwork projects (Cuisinier et al., 2011; Hashemi et al., 2015; Metelková et al., 2012). In this context, effective changes in soil properties, such as improvements in structure, stability, porosity, and aggregate strength, have been mentioned for silty and clayey soils (Little, 1995).

Quicklime reacts with water to form calcium hydroxide $\left(\mathrm{Ca}(\mathrm{OH})_{2}\right)$. The solubility product of $\mathrm{Ca}(\mathrm{OH})_{2}\left(5.02 \times 10^{-6}\right)$ is three orders of magnitude higher than that of $\mathrm{CaCO}_{3}$ $\left(3.36 \times 10^{-9}\right)$ (Haynes, 2013), which has the consequence that it dissolves and reacts much faster. Hence, quicklime quickly reacts with clay in the soil and leads to a change in its structure, with clay minerals coalescing into larger aggregates (Little, 1995). The calcium ions from quicklime can replace other ions $\left(e g \mathrm{Na}^{+}, \mathrm{K}^{+}, \mathrm{Mg}^{2+}, \mathrm{H}^{+}\right)$in the clay

(C) 2016 Institute of Agrophysics, Polish Academy of Sciences 
interlayers or on the surface of clay particles, which in turn favours flocculation; this process is strongly dependent on the soil cation exchange capacity (CEC). Flocculation was found to occur immediately after quicklime addition and to continue for several days (Metelková et al., 2012).

We hypothesised that, due to its higher solubility, quicklime can improve soil aggregate stability more rapidly than limestone when applied at the same rate.

To test this hypothesis, a greenhouse pot experiment was conducted using the two above-mentioned liming materials and investigating their effects on soil aggregate stability over time.

\section{MATERIALS AND METHODS}

The soil samples for the greenhouse pot experiment were taken in August 2013 from the plough layer $(0-15 \mathrm{~cm})$ of three agricultural soils of Austria located in Strengberg, Pollham and Kemeten (Table 1). The soils are classified as Stagnosols with silty/clayey texture and an organic carbon $\left(\mathrm{C}_{\text {org }}\right)$ content between 1.3 and 1.8\% (Table 2). The selected soils are intensively managed agricultural soils with fine textures; they are therefore prone to compaction and well suited to the question under investigation. From each location, homogenised soil material was brought to the greenhouse within one day. After crushing and sieving $(<10 \mathrm{~mm})$, the samples were air dried (to approx. $10 \% \mathrm{w} / \mathrm{w}$ water content) and stored in open pots.
Each of 36 pots $(27.5 \mathrm{~cm}$ in diameter and $21.5 \mathrm{~cm}$ in height) was filled with washed coarse gravel up to about $2 \mathrm{~cm}$ and overlaid by a water permeable textile. Then, 11 to $12 \mathrm{~kg}$ of the sieved and well homogenised, dry soil material was added. To double-check the homogeneous filling of the pots, the soil texture was tested in $1 \mathrm{~cm}$ increments for location 'Pollham'. The average clay content of this sample pot was $26.7 \%$ and varied among the $1 \mathrm{~cm}$ increments only within a small range of about $\pm 0.48 \%$, confirming that the pots were filled homogeneously. For water saturation to an average of about $25 \% \mathrm{w} / \mathrm{w}$, the soils were capillary-wetted from the bottom for $24 \mathrm{~h}$ to reach homogeneity, which is essential for soil physical experiments. For equilibration prior to lime application, the pots were pre-incubated at ambient temperature and approximately $25 \% \mathrm{w} / \mathrm{w}$ soil water content in the greenhouse for one month (water contents at each sampling are given in Table 3 ).

Quicklime $(\mathrm{CaO})$ and limestone $\left(\mathrm{CaCO}_{3}\right)$ were added in pulverised form at an application rate of $2000 \mathrm{~kg} \mathrm{ha}^{-1}$ and incorporated into the upper $7 \mathrm{~cm}$. Within the greenhouse, the pots were positioned in a randomised block design to reduce the influence of factors such as solar radiation, temperature etc. The pots were sampled 2, 30 and 86 days after lime application. At each sampling time, one pot was destructively sampled and the material was used for aggregate stability testing in three replicates.

The method for aggregate stability determination is based on a common standard by the Austrian Standards Institute (OENorm-L1072, 2004). Although this is a local

T a b l e 1. Site conditions and soil texture

\begin{tabular}{|c|c|c|c|c|c|c|c|}
\hline \multirow{2}{*}{ Site } & Location & \multirow{2}{*}{ Soil type } & Elevation & \multirow{2}{*}{ Crop } & Clay & Silt & Sand \\
\hline & (GPS position) & & \multicolumn{2}{|l|}{ (m a.s.1.) } & & \multicolumn{2}{|l|}{$(\%)$} \\
\hline Strengberg & $\begin{array}{l}\mathrm{N}: 48^{\circ} 09^{\prime} 14.24^{\prime \prime} \\
\mathrm{E}: 14^{\circ} 36^{\prime} 8.00^{\prime \prime}\end{array}$ & \multirow{3}{*}{ Stagnosol } & 346 & maize & 34.2 & 56.6 & 9.2 \\
\hline Pollham & $\begin{array}{l}\mathrm{N}: 48^{\circ} 14^{\prime} 55.31^{\prime \prime} \\
\mathrm{E}: 13^{\circ} 51^{\prime} 39.31^{\prime \prime}\end{array}$ & & 385 & wheat & 26.5 & 60.7 & 12.8 \\
\hline Kemeten & $\begin{array}{l}\mathrm{N}: 47^{\circ} 14^{\prime} 37.56^{\prime \prime} \\
\mathrm{E}: 16^{\circ} 10^{\prime} 14.10^{\prime \prime}\end{array}$ & & 315 & soy bean & 39.6 & 32.2 & 28.2 \\
\hline
\end{tabular}

T a b l e 2. Basic chemical soil parameters

\begin{tabular}{|c|c|c|c|c|c|c|c|c|}
\hline \multirow{2}{*}{ Site } & $\mathrm{C}_{\text {org }}$ & $\mathrm{SOM}$ & $\mathrm{N}_{\text {tot }}$ & $\mathrm{CEC}_{\text {pot }}$ & \multirow{2}{*}{$\mathrm{pH}_{\mathrm{KCl}}$} & $\begin{array}{c}\text { Electrical } \\
\text { conductivity }\end{array}$ & $\mathrm{C} / \mathrm{N}$ ratio & $\mathrm{CaCO}_{3}$ \\
\hline & $(\%)$ & $(\%)$ & $\left(\mathrm{mg} \mathrm{kg}^{-1}\right)$ & $\left(\mathrm{mmol}_{\mathrm{c}} 100 \mathrm{~g}^{-1}\right)$ & & $\left(\mathrm{mS} \mathrm{cm}{ }^{-1}\right)$ & $\left(1^{*}\right)$ & $(\%)$ \\
\hline Strengberg & 1.77 & 3.05 & 1850 & 20.58 & 6.43 & 0.983 & 9.5 & - \\
\hline Pollham & 1.69 & 2.91 & 1550 & 12.22 & 7.63 & 0.720 & 10.9 & 7.1 \\
\hline Kemeten & 1.31 & 2.25 & 1260 & 22.04 & 5.27 & 0.212 & 10.4 & - \\
\hline
\end{tabular}

*Mass ratio. 
T a b l e 3. Soil acidity $(\mathrm{pH})$ and water content. Response to lime application over time

\begin{tabular}{|c|c|c|c|c|c|c|c|c|}
\hline \multirow{2}{*}{ Site } & \multirow{2}{*}{$\begin{array}{l}\text { Days after } \\
\text { application }\end{array}$} & \multicolumn{3}{|c|}{$\mathrm{pH}\left(\right.$ in $0.01 \mathrm{M} \mathrm{CaCl}_{2}$ ) } & \multirow{2}{*}{ p-values } & \multicolumn{3}{|c|}{ Water content $(\% \mathrm{w} / \mathrm{w})$} \\
\hline & & control & $\mathrm{CaCO}_{3}$ & $\mathrm{CaO}$ & & control & $\mathrm{CaCO}_{3}$ & $\mathrm{CaO}$ \\
\hline \multirow{3}{*}{ Strengberg } & 2 & $6.8 \mathrm{abc}$ & $7.4 \mathrm{c}$ & $9.6 \mathrm{~d}$ & lime $\mathrm{p}<0.01$ & 23.7 & 23.3 & 24.0 \\
\hline & 30 & $6.5 \mathrm{a}$ & $6.8 \mathrm{abc}$ & $7.2 \mathrm{bc}$ & time $\mathrm{p}<0.001$ & 22.8 & 22.7 & 22.4 \\
\hline & 86 & $6.6 \mathrm{ab}$ & $6.5 \mathrm{a}$ & $6.8 \mathrm{ab}$ & lime $\mathrm{x}$ time $\mathrm{p}<0.001$ & 22.3 & 22.7 & 23.5 \\
\hline \multirow{3}{*}{ Pollham } & 2 & $7.3 \mathrm{ab}$ & $7.4 \mathrm{ab}$ & $10.5 \mathrm{c}$ & lime $\mathrm{p}<0.001$ & 24.4 & 25.7 & 24.1 \\
\hline & 30 & $7.2 \mathrm{ab}$ & $7.2 \mathrm{ab}$ & $7.7 \mathrm{~b}$ & time $\mathrm{p}<0.001$ & 22.1 & 23.7 & 23.1 \\
\hline & 86 & $7.0 \mathrm{ab}$ & $7.0 \mathrm{a}$ & $7.0 \mathrm{ab}$ & lime $\mathrm{x}$ time $\mathrm{p}<0.001$ & 25.0 & 24.9 & 24.8 \\
\hline \multirow{3}{*}{ Kemeten } & 2 & $5.4 \mathrm{a}$ & $7.0 \mathrm{~d}$ & $8.3 \mathrm{e}$ & lime $\mathrm{p}<0.001$ & 25.9 & 25.3 & 24.9 \\
\hline & 30 & $5.4 \mathrm{a}$ & $6.5 \mathrm{~cd}$ & $6.9 \mathrm{~d}$ & time $\mathrm{p}<0.001$ & 20.3 & 19.4 & 20.1 \\
\hline & 86 & $5.6 \mathrm{ab}$ & $6.1 \mathrm{~b} \mathrm{c}$ & $6.3 \mathrm{bcd}$ & lime $\mathrm{x}$ time $\mathrm{p}<0.001$ & 22.6 & 22.0 & 21.9 \\
\hline
\end{tabular}

Different letters for the same site indicate differences in multiple comparison of mean by Tukey HSD ( $\mathrm{p}<0.05$ with a confidence level of 95\%); the $\mathrm{p}$ values for 'lime' (form of lime), 'time' (time after application) and 'lime $\mathrm{x}$ time' are from a 2-way ANOVA (confidence level of $95 \%$ ) and indicate significance of the individual factors or their interaction.

standard, it can be compared to internationally used methods, eg Dane et al. (2002) and Kemper and Rosenau (1986). Generally, the method is based on a wet sieving procedure of air dried soil samples. The sieving frequency is 42 hubs per minute, hub height is $2 \mathrm{~cm}$ whereby the soil sample is always covered by water. Sample size is $20 \mathrm{~g}$. The mass of stable aggregates in the dimension of 1-2 mm was determined using a modified wet sieving equipment (Murer et al., 1993).

Soil $\mathrm{pH}$ was measured in a $0.01 \mathrm{M} \mathrm{CaCl}_{2}$ suspension (OENorm-L1083, 1999). $2.0 \mathrm{~g}$ of soil was suspended in $25 \mathrm{ml} \mathrm{CaCl}_{2}$ solution and, after incubation for at least $2 \mathrm{~h}$ at room temperature, the $\mathrm{pH}$ value was determined with a calibrated pH-meter (Mettler Toledo, SG2; Vienna, Austria)

At each sampling, the gravimetric water content was determined from $2.3 \mathrm{~g}$ of soil by drying at $105^{\circ} \mathrm{C}$ for $24 \mathrm{~h}$; values are given in Table 3 .

Statistical analyses were performed using Statgraphics Centurion XVI (StatPoint Technologies, Inc, USA). Differences between treatments were tested with oneway ANOVA. For each location, the effects of lime and time were investigated using 2-way ANOVA with treatment ('lime') and sampling time ('time') as fixed factors. Significant differences were shown by Tukey HSD test at a confidence interval of $95 \%$. The graphs were created with SigmaPlot 12.5.

\section{RESULTS AND DISCUSSION}

The liming effect of the applied limestone and quicklime materials was assessed by monitoring changes in soil acidity (Table 3). The application of $\mathrm{CaCO}_{3}$ caused an increase in $\mathrm{pH}$ for site Kemeten which originally had an acidic soil $\mathrm{pH}$; however, no significant changes were observed for the other two sites. The minor changes in soil $\mathrm{pH}$ with $\mathrm{CaCO}_{3}$ in our study might be due to a delayed reaction and/or significantly lower application rates compared to other studies $\left(\sim 18 \mathrm{t} \mathrm{ha}^{-1}\right)$ (Acosta-Martínez and Tabatabai, 2000; Fuentes et al., 2006). On the other hand, the application of $\mathrm{CaO}$ resulted in an immediate and much stronger increase of soil $\mathrm{pH}$ at all the sites (Table 3), but decreased at the third sampling (after 3 months) to the reference values of the controls. This is one indication for the quicker reaction of $\mathrm{CaO}$ compared to $\mathrm{CaCO}_{3}$ due to its higher solubility in the soil.

Many studies have investigated the effects of organic matter and limestone on stable aggregates in soils (Chenu et al., 2000; Six et al., 2002; Spaccini and Piccolo, 2013). However, studies on the effects of quicklime in the context of soil sciences are scarce, or the specification is not clear, as a large body of literature only mentions the term 'lime' without further details on the material used. Quicklime and its ability to stabilise aggregates is described mostly in engineering papers (Beetham et al., 2014; Cuisinier et al., 2011; Idiart et al., 2012), whereas its potential application in agricultural soils has attracted less scientific attention. 


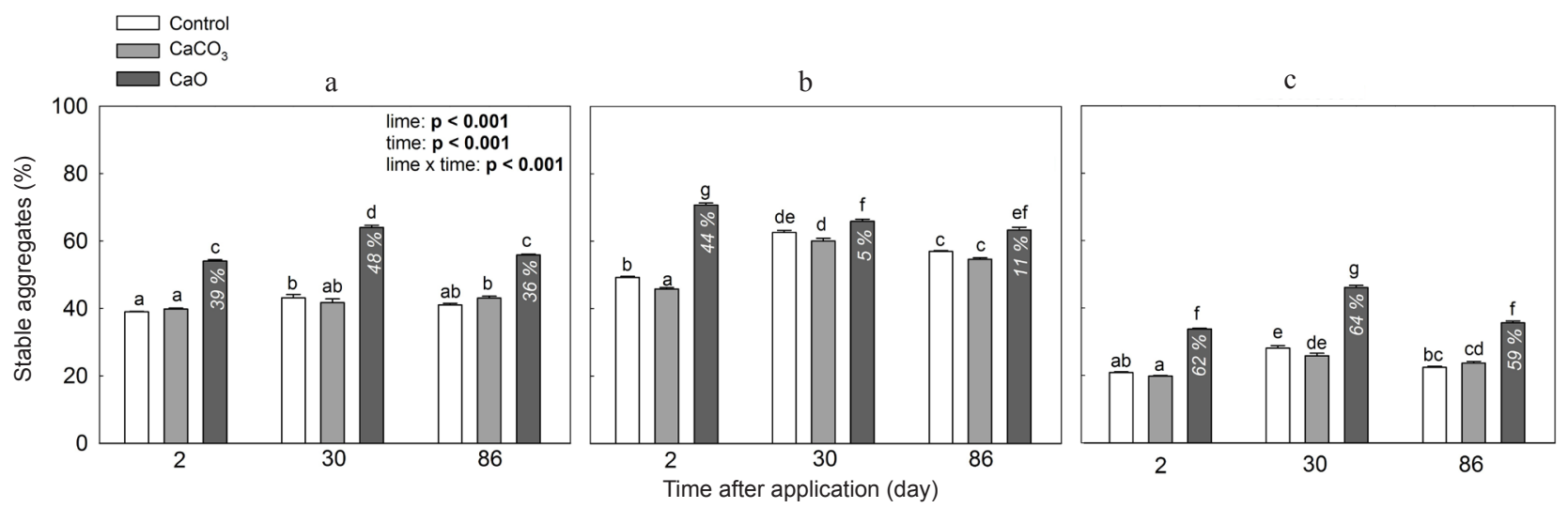

Fig. 1. Stable aggregates in mass \% for the sites: a - Strengberg, b - Pollham and c - Kemeten. Different letters for the same site indicate differences in multiple comparison of mean by Tukey HSD $(\mathrm{p}<0.05$ with a confidence level of $95 \%)$; the $\mathrm{p}$ values for 'lime' (form of lime), 'time' (time after application) and 'lime x time' are from a 2-way ANOVA (confidence level of 95\%) and indicate significance of the individual factors or their interaction. The percentage given in the dark grey bars $(\mathrm{CaO})$, indicates the increase in stable aggregates relative to the control.

Therefore, our study analyses limestone and quicklime application as strategies for restoring structural stability in degraded agricultural soils. Our results clearly show a significant and instantaneous increase of stable aggregates after quicklime application (Fig. 1). This effect was measured already after 2 days and was sustained for the entire duration of the experiment (3 months). The effect of quicklime application on aggregate stability was strongly dependent on soil type and sampling time. The strongest effect was observed for site Kemeten which showed a relative increase in stable aggregates between 59 and $65 \%$ compared to the control over the entire course of the trial. The smallest increase in stable aggregates was observed for site Pollham, where it was only 5 and $11 \%$ compared to the control for the 2nd and 3rd sampling, respectively. The effect of quicklime on soil aggregate stability seems to be related to the soils clay content and cation exchange capacity (CEC): the soil of site Kemeten had the highest clay content and CEC, while this was opposite for Pollham soil (Table 2). Hence, the flocculating effect of added $\mathrm{Ca}^{2+}$ seems to increase with higher surface area (clay content) and available exchange sites (CEC). The lowest increase in aggregate stability at site Pollham could also be attributed to the fact that this soil already contained carbonate (Table 2) and showed relatively high aggregate stability, reducing the potential effect of additional liming. Also, the temporal trend of stable aggregates in the soil from site Pollham is interesting, as it clearly differed from the other two sites, showing a strong initial increase immediately after application of $\mathrm{CaO}$ (Fig. 1). A possible explanation for this may be the $\mathrm{pH}$ which reached 10.5 directly after the application (Table 3). Dissolution of clay minerals into silicate and aluminate species may occur under such highly alkaline conditions (Hashemi et al., 2015), and pozzolanic reaction may take place (Metelková et al., 2012). Hence, such high $\mathrm{pH}$ conditions may be favourable for improved workability and reduced swelling and plasticity of soils, desirable for geotechnical applications. However, in agricultural soils this is an unwanted side effect of quicklime application as these environments might be exceptionally unfavourable for nutrient availability.

In addition to soil texture and CEC, also soil organic matter (SOM) content may influence the efficiency of lime application (Hashemi et al., 2015). Organic coatings on soil particles may inhibit the flocculation reaction by decreasing the availability of mineral surfaces for sorption of polyvalent ions (Cook and Batchelor, 1996). It is supposed that SOM content above $1 \%$ reduces the reactivity of lime. All three soils under study showed SOM contents above two percent (Table 2), and the soil from Kemeten, which showed the largest increase in stable aggregates upon quicklime application, had indeed the lowest SOM of the studied soils (Table 2).

Contrary to the marked improvement of aggregate stability after quicklime application, there were no significant effects after the application of limestone. The results were similar for soils from all three locations and indicate once more that $\mathrm{CaO}$ reacts much faster than $\mathrm{CaCO}_{3}$ because of its higher solubility in the soil.

Several studies reported an increase in aggregate stability in the long term after limestone application (Bennett et al., 2014; Castro and Logan, 1991). However, we did not even see a delayed effect of $\mathrm{CaCO}_{3}$ on aggregate stability after 3 months. One possible explanation is that $\mathrm{CaCO}_{3}$ needs to be applied at higher rates to show similar effects as $\mathrm{CaO}$ in our short-term experiment. On the other hand, also reduced aggregate stability was reported, especially for tropical acidic soils, after the application of $\mathrm{CaCO}_{3}$ 
(Roth and Pavan, 1991; Tarchitzky et al., 1993). Such negative effects were determined only shortly (1 to 3 months) after limestone application at low rates (Roth and Pavan, 1991). However, in the longer-term (after 6 months), soil aggregation was reported to increase substantially, while the initial negative effect was less pronounced at higher application rates. The rate applied in our experiment was selected according to the Austrian guidelines for agricultural soil fertilisation and should be of practical relevance (Baumgarten, 2006).

Our study demonstrates that quicklime can rapidly and sustainably improve the aggregate stability of agricultural soils. This confirms the results from studies in engineering also for agriculture, even though the application rate in our experiment was one order of magnitude lower than those reported for engineering studies. We assume that the application of $\mathrm{CaCO}_{3}$ may show beneficial effects on soil aggregate structure in the long-term and at higher application rates. The results support our hypothesis that quicklime can improve soil aggregate stability more rapidly than limestone. Quicklime application, therefore, seems to be a feasible strategy for rapid improvement of aggregate stability, particularly in intensively managed/trafficked agricultural soils prone to compaction and degradation.

\section{CONCLUSIONS}

1. Quicklime application shows a significant and instantaneous increase of stable aggregates.

2. The increase of stable aggregates due to the application of quicklime was observed already after 2 days and was sustained for the entire duration of the experiment (3 months).

\section{REFERENCES}

Acosta-Martínez V. and Tabatabai M.A., 2000. Enzyme activities in a limed agricultural soil. Biol. Fert. Soils, 31, 85-91.

Amezketa E., 1999. Soil aggregate stability: a review. J. Sustain Agr., 14, 83-151.

Baumgarten A., 2006. Richtlinien für die sachgerechte Düngung. Bundesministerium für Land- und Forstwirtschaft, Vienna, Austria.

Becher H., 2001. Influence of long-term liming on aggregate stability of a loess-derived soil. Int. Agrophysics, 15, 67-72.

Beetham P., Dijkstra T., Dixon N., Fleming P., Hutchison R., and Bateman J., 2014. Lime stabilisation for earthworks: a UK perspective. Proc. ICE-Ground Improvement, 168, 81-95.

Bennett J.M., Greene R.S.B., Murphy B.W., Hocking P., and Tongway D., 2014. Influence of lime and gypsum on longterm rehabilitation of a Red Sodosol, in a semi-arid environment of New South Wales. Soil Res., 52, 120-128.

Bergström L., Kirchmann H., Djodjic F., Kyllmar K., Ulén B., Liu J., Andersson H., Aronsson H., Börjesson G., and Kynkäänniemi P., 2015. Turnover and losses of phosphorus in Swedish agricultural soils: Long-term changes, leaching trends, and mitigation measures. J. Environ. Qual., 44, 512-523.
Briedis C., Sá J.C.d.M., Caires E.F., Navarro J.d.F., Inagaki T.M., Boer A., Neto C.Q., Ferreira A.d.O., Canalli L.B., and Santos J.B.d., 2012. Soil organic matter pools and carbon-protection mechanisms in aggregate classes influenced by surface liming in a no-till system. Geoderma, 170, 80-88.

Castro C. and Logan T., 1991. Liming effects on the stability and erodibility of some Brazilian Oxisols. Soil. Sci. Soc. Am. J., 55, 1407-1413.

Chenu C., Le Bissonnais Y., and Arrouays D., 2000. Organic matter influence on clay wettability and soil aggregate stability. Soil. Sci. Soc. Am. J., 64, 1479-1486.

Cook E.R. and Batchelor B., 1996. Chapter 4 Stabilization/ solidification of hazardous wastes in soil matrices. In: Advances in Porous Media (Ed. M.Y. Corapcioglu). Elsevier, Texas, USA.

Cuisinier O., Auriol J.-C., Le Borgne T., and Deneele D., 2011. Microstructure and hydraulic conductivity of a compacted lime-treated soil. Eng. Geol., 123, 187-193.

Dane J.H., Topp C., Campbell G.S., Horton R., Jury W.A., Nielsen D.R., van Es H.M., Wierenga P.J., and Topp G.C., 2002. Part 4. Physical Methods. Methods of Soil Analysis. Soil Science Society of America, Madison, WI, USA.

Frey B., Kremer J., Rüdt A., Sciacca S., Matthies D., and Lüscher P., 2009. Compaction of forest soils with heavy logging machinery affects soil bacterial community structure. Eur. J. Soil Biol., 45, 312-320.

Fuentes J.P., Bezdicek D.F., Flury M., Albrecht S., and Smith J.L., 2006. Microbial activity affected by lime in a long-term notill soil. Soil Till. Res., 88, 123-131.

Hashemi M., Massart T., Salager S., Herrier G., and François B., 2015. Pore scale characterization of lime-treated sandbentonite mixtures. Appl. Clay Sci., 111, 50-60.

Haynes R. and Naidu R., 1998. Influence of lime, fertilizer and manure applications on soil organic matter content and soil physical conditions: a review. Nutr. Cycl. Agroecosys., 51, 123-137.

Haynes W.M., 2013. CRC handbook of chemistry and physics. CRC Press, Boca Raton, FL, USA.

Idiart A., Bisschop J., Caballero A., and Lura P., 2012. A numerical and experimental study of aggregate-induced shrinkage cracking in cementitious composites. Cement Concrete Res., 42, 272-281.

Kemper W.D. and Rosenau R.C., 1986. Aggregate stability and size distribution. In: Methods of Soil Analysis (Ed. A. Klute). Agron. Monogr. 9, ASA and SSSA, Madison, WI, USA .

Little D.N., 1995. Stabilization of pavement subgrades and base courses with lime. Dubuque (Iowa), Published by Kendall/ Hunt Publishing Company.

Matson P.A., Parton W.J., Power A., and Swift M., 1997. Agricultural intensification and ecosystem properties. Science, 277, 504-509.

Metelková Z., Boháč J., Přikryl R., and Sedlářová I., 2012. Maturation of loess treated with variable lime admixture: Pore space textural evolution and related phase changes. Appl. Clay Sci., 61, 37-43.

Murer E.J., Baumgarten A., Eder G., Gerzabek M., Kandeler E., and Rampazzo N., 1993. An improved sieving machine for estimation of soil aggregate stability (SAS). Geoderma, $56,539-547$.

Oades J., 1988. The retention of organic matter in soils. Biogeochemistry, 5, 35-70. 
OENorm-L1072, 2004. Physikalische Bodenuntersuchungen. Bestimmung der Aggregatstabilität nach dem Siebtauchverfahren. Austrian Standards Institute, Vienna, Austria.

OENorm-L1083, 1999. ChemischeBodenuntersuchungen. Bestimmung der Acidität (pH-Wert). Austrian Standards Institute, Vienna, Austria.

Roth C. and Pavan M., 1991. Effects of lime and gypsum on clay dispersion and infiltration in samples of a Brazilian Oxisol. Geoderma, 48, 351-361.

Six J., Conant R., Paul E., and Paustian K., 2002. Stabilization mechanisms of soil organic matter: implications for C-saturation of soils. Plant Soil, 241, 155-176.

Spaccini R. and Piccolo A., 2013. Effects of field managements for soil organic matter stabilization on water-stable aggregate distribution and aggregate stability in three agricultural soils. J. Geochem. Explor., 129, 45-51.

Tarchitzky J., Chen Y., and Banin A., 1993. Humic substances and $\mathrm{pH}$ effects on sodium-and calcium-montmorillonite flocculation and dispersion. Soil Sci. Soc. Am. J., 57, 367-372.

Ulén B. and Etana A., 2014. Phosphorus leaching from clay soils can be counteracted by structure liming. Acta Agriculturae Scandinavica, Section B-Soil Plant Sci., 64, 425-433.

VDLUFA, 2000. Bestimmung des Kalkbedarfs von Acker - und Grünlandböden. Verband Deutscher Landwirtschaftlicher Untersuchungs- und Forschungsanstalten (VDLUFA), Darmstadt. 